\title{
Ethical Judgment and Humorous Advertising
}

\author{
Ines saadellaoui* \\ Ph.D in Marketing, Higher Institute of Management of Gabes (I.S.G), University of Gabes Laboratory League, La Manouba, Tunisia.
}

Published: April 24, 2018

*Corresponding author: Ines Saadellaoui, Ph.D in Marketing, Higher Institute of Management of Gabes ( I.S.G), University of Gabes, Laboratory League, La Manouba, Tunisia. , Email: ines.saadellaoui@gmail.com

\begin{abstract}
Humor is widely used in persuasion in both advertising and education. Funny ads are more likely to be enjoyable and involving, and therefore memorable, than others. However, some researchers point out that humor in advertising is risky. It can be devastatingly effective. It can raise ethical issues. It was noted that little research has been paid to the subject of consumers' ethical judgment of a humorous advertising in social marketing. The purpose of this article is to better understand the effects of perception of the ethicality of humorous advertising on persuasion and behavioral intention. A conceptual model is proposed and tested. A sample of 390 smokers was retained to test the model. In order to test the hypotheses, we adopt an exploratory approach with SPSS 20. The structural equation model was utilized using AMOS 20 software. The results show that the perceived ethicality of humorous campaigns is necessary to improve its effectiveness. This study provides a framework and guidance for the development of public health communication campaigns relying on effective and ethical humor.
\end{abstract}

Keywords: Ethical judgment; Humor; Persuasion; Behavioral intention; Anti-smoking advertisements

\section{Introduction}

One-third of the population smokes worldwide. Deaths and diseases due to smoking are inevitable. 'Tobacco mortality has been estimated at about 4 million deaths in 1998 and is expected to reach almost 10 million a year by 2030, of which $70 \%$ is in developing countries' World Health Organization [1]. Smoking prevalence is high in Tunisia, especially in male. Nearly 55\% of the male population and between $5 \%$ and $20 \%$ of the adult female population smokes Hsairi [2]. This shows that the tobacco epidemic is well established in Tunisia and that it is increasingly affecting the populations that were traditionally protected, namely women and children. In addition, several studies showed a high prevalence of smoking among young people DMSU Surveys, 2000, Global Youth Tobacco Survey, Tunisia 2010 with smoking initiation at 13 Global Youth Tobacco Survey, Tunisia 2010. This smoking-endemic situation accounts for nearly one in five deaths among men over 25. Mortality attributable to tobacco is estimated at 6430 deaths in 1997 of which 5580 are men and 850 are women. For men, tobacco causes 3050 deaths due to cardiovascular disease and 1.500 deaths due to cancer. $92 \%$ of the cancer deaths are caused by tobacco Hsairi [2]. This shows that there is an urgency of fighting this scourge and understanding the determinants of the intention to stop smoking.

Despite efforts by the National Institute of Public Health and other non-governmental organizations to persuade smokers to get rid of this bad habit, the persuasive capacity of anti-smoking is weak Fakhfakh et al. [3]. They are generally focused on the negative effects of passive and active smoking. Many studies point out the lack of an advertisements to discourage unhealthy behavior: driving in a state of intoxication, smoking Smith [4]; Lewis et al. [5]. Therefore, the choice of appropriate discourse is crucial. It was noted that smokers underestimate the dangers of cigarettes. They minimize the devastation associated with the consumption of this product Paquette [6].

In a study carried out in 2000 by the National Institute of Prevention and Education for Health to determine the most relevant publicity registers, it was found that young people between 11 and 30 years old are admired by films which have become for them 'a spectacle of pleasure" Fleur [7]. In addition, it appears that this target is attracted by messages that are focused on strong emotions such as fear, humor and despair Oddoux [8]. In the same vein Riou [9] states that with the advent of postmodern culture, new communication codes are emerging; entertainment, connivance, humor, seduction. It is essential to move from a mode of persuasion to a mode of seduction as do private brands. Various types of strategies can therefore be implemented in the field of social marketing in order to achieve the advertiser's ultimate goal of convincing individuals to change their ideas or behaviors. This study will first present the research problem and objectives. Then a brief review of the 
literature is mentioned. Next, we will present the assumptions and methodology. Finally, the main findings and the research practical implications will be detailed.

\section{The research problem}

Humor is a complex construct that has been studied by linguists, philosophers, psychologists, and scholars from many disciplines, including of course advertising. Much research has been conducted on the impact of humor on advertising persuasion Madden [10]; Zhang [11]; Zinkhan [12]. Contrary to the concept of fear which is easier to define and widely used in social advertising, it should be noted that most of the research carried out on the theme of humor and persuasion concerns more commercial ads than social marketing Brooker [13]; De Barnier et al. [14]. Humor is also effective in fighting drug use and cigarette smoking or in convincing drivers to adopt healthy behaviors Kapferer [15]; Gallopel [16]; Graby [17]; Hastings et al. [18]. It should also be noted that there is some controversy among researchers as to the ethical nature of humor which constitutes an aspect of provocation Hyman [19]. A first group of researchers argues that the use of emotional campaigns is relevant and ethical in promoting healthy behaviors and contributing to the preservation of individual and community well-being Gallopel [20]; Gregory [21] note, for example, that "it can be said that the end sometimes justifies the means. Fear for example if the other creative axes are not effective, is acceptable if it leads to less speed, less smoking or even to protect oneself from AIDS or cancer'. The humor is widely used as an aid to persuasive messages such as advertisements and lessons plans. It keeps the attention of the prospect and it makes the message easier to remember. However, a second group of researchers denounce the use of these emotions that reflect the lack of responsibility on the part of advertisers. Mostafa [22] reports that Egyptians have a negative attitude towards unethical advertising.

In the same vein, several studies have shown that an unethical announcement can have very negative repercussions in the short and long term Thompson [23]; Eckart [24]; PalmerMehta [25]. In addition, the use of humor is tricky. Sometimes a funny message is badly perceived. Several communications are rejected by prospects because of funniness that hurts unnecessarily Teyssier [26]; Alden [27] reports that humor can be detrimental to memorizing the brand when misused or overused. Similarly, Caples in Brochand and Lendrevie [28] argue that humor must be used with caution because public reactions are unpredictable and remain very personal. He recommends 'to avoid humor: what is fun for a person is not for millions. The role of advertising is to sell not to entertain'. Humor can offend or shock viewers. Humorous advertising is an ethical form of advertising. This controversy or the absence of a consensus on the perception of the ethical character of anti-smoking messages based on humor is the essence of our research problem since we try to study the effect of the ethical judgment of humorous advertising on the persuasion and the intention to quit smoking.

\section{Conceptual Framework of the Study}

\section{The ethical judgement}

Ethical judgement is the degree to which an individual believes that a specific behavior is morally acceptable' Snipes [28]; Reidenbach [29] suggest that this concept has three dimensions relating to moral equity, relativism and contractualism. The moral dimension of equity is composite. It is associated with moral philosophies of justice, the ethical approach and the relativistic approach. The second dimension focuses on the instructions, and requirements of cultural and social system. The third dimension depends on the notions of obligation, contracts, duties and rules. The researchers argue that the dimensions of moral equity and relativism are more appropriate than the contractual dimension in advertising studies Arthur and Quester, 1994; La Tour [30]; Snipes [28]. Therefore, the last dimension will be excluded in this study. It should be noted that research on ethics and advertising deserves much more attention of researchers to be interested in increasing the effectiveness of an advertising message. Communication practices ought to be responsible. Ethics therefore constitute a basis for the judgment of the consumer who in turn acts on persuasion.

\section{Behavioral intention}

Intention is an intermediate conative component between attitude and behavior Fishbein [31]. It represents the desire, determination or willingness to behave. Ajzen 1990 states that intention is 'the effort that the individual is willing to behave. Ajzen [32] states that intention is 'the effort that the individual is willing to provide to perform the behavior'. According to Eagly [33] intentionis 'a person's conscious level of exerting an effort to achieve behavior. The literature highlights the existence of two theoretical approaches explaining behavioral intention, which are the theory of reasoned action and the theory of planned behavior. The theory of reasoned action was developed by Fishbein [31]. It aims to predict intention based on attitude and subjective norms Fishbein [31]. On the other hand, the theory of planned behavior incorporates a third explanatory variable, that of perceived control Ajzen [34]. The theory of reasoned action assumes that the intention of an individual to adhere to a behavior is dependent on his own attitude towards the performance of that act and the subjective norm the attitude refers to the set of beliefs about the consequences of conducting behavior and evaluating of these consequences. However, subjective norms refer to the set of normative beliefs and the individual's motivation to comply with the norms Fischbein [31]; Fishbein [35].

The conception we adopt of the intention is that proposed by the theory of planned behavior. The theory states that attitude toward behavior, subjective norms, and perceived behavioral control, together shape an individual's behavioral intentions and behaviors. It has been applied to studies of the relations among beliefs, attitudes, behavioral intentions and behaviors in various 
fields such as public relations, advertising campaigns and healthcare. Indeed, a moral aspect is a common denominator between the ethical judgement of advertising and subjective norms. They are determined by normative beliefs Fishbein [35]. Subjective normsare 'an individual's perception about the particular behavior, which is influenced by the judgment of significant others (e.g., parents, spouse, friends, teachers)'. However, Normative belief is 'an individual's perception of social normative pressures, or relevant others' beliefs that he or she should or should not perform such behavior' Fishbein [31]. Subjective norms introduce the idea of family acceptance. The adoption of a tone that does not correspond to the subjective norms of the individual leads to the rejection of advertising arguments and has a negative effect on the intention to stop smoking.

\section{Persuasion}

Preston [36] states that persuasion is 'communication about the adoption by a person or group of a product, person, idea, entity or point of view that person does not support'. According to Derbaix [21], persuasion is the formation or modification of the attitude or beliefs with regard to the object promoted (brand, person, and institution). A persuasive communication is a communication whose primary objective is to persuade, that is to say to provoke a change in the way of thinking or in the behavior in the sense recommended by the sponsor or author of this communication Dacheux [37].

\section{Conceptual model}

The proposed model investigates how the perceived morality of humour in social advertising impacts the intention to quit smoking. The contribution of this research is to show that the consumer adopts a message only if it is accepted ethically. Advertising discourse can only bring about action when it is deemed ethical. The theoretical framework within which our research is based on Habermas [38,39] theory of communicative action. The effectiveness of advertising is best achieved by using intercomprehension communications. Habermas $[38,39]$ recommends avoiding instrumental and strategic communications. Figure 1 presents this model.

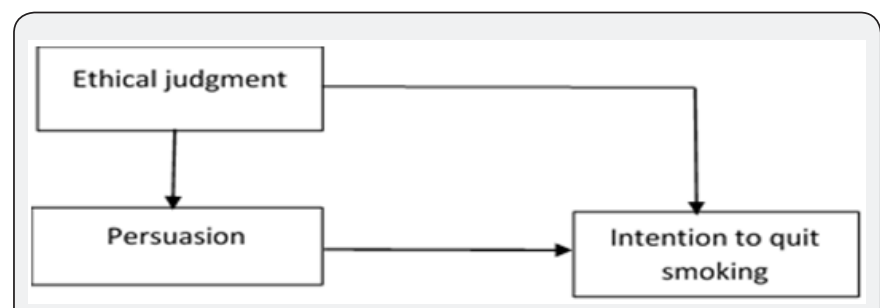

Figure 1: Conceptual model.

\section{Hypotheses}

Previous research identify two important cognitive responses: counterarguments and favorable thoughts in persuasion settings Festinger [40]; Wells [41]; Petty [42] points out 'for example, while listening to an editorial in favor of raising taxes, the recipient might covertly counterargue (e.g., «No way! The government wastes $50 \%$ of everything we give them") or generate favorable cognitive responses (e.g., «This is a good idea, we will be able to give more to the poor»]'. Petty [42] underlines that the change of attitude is postulate to be a function of the dominance of one type of response over the other.

Persuasion reflects the degree of acceptance of a message Derbaix [21]. It should be noted that a message generating favorable thoughts increases the effectiveness of the announcement. Several authors point out that counter-arguments negatively affect the change of attitude Brock [43]; Petty and Cacioppo 1979. This will negatively affect behavioral intention. Hence, H1: Persuasion has an effect on intention to quit smoking. Humor is a multidimensional, vague concept Weinberger [44] and difficult to define scientifically Brooker [13]; Graby [17]. It has been the subject of many definitions. We shall repeat the most popular ones: Air is breathable to man only if, in addition to oxygen and carbon dioxide, it contains traces of humor" Elgozy [45]. This statement emphasizes the omnipresence and importance of 'this form of mind' as the privileged technique of persuasion. It is also 'the double grace of intelligence and sensibility" Escarpit in Graby [17]. Much research has been conducted on the impact of humor on advertising persuasion Madden [46]; Alden [27]; Zinkhan [12]; Biel [47] points out that liking an advertisement increases persuasion. In the same vein, Biel [47] argues that the ingenuity that characterizes 'smart, imaginative, fun, original, not stupid, not bland' advertising is a component of enjoyment. The perception of humor in fact arouses positive emotions such as joy, stimulation, surprise and satisfaction. Faced a humorous advertisement, the consumer is distracted. This positive perception of the advertising message translates into a positive attitude and therefore favors the acceptance of advertising arguments Mc Quarrie [48]. Plutonic studies highlight that humor is also effective in fighting drug use and cigarette smoking Hastings et al. [18].

It is noteworthy that what is considered by some to be humor can be regarded by others as a nasty mockery or insult Graby [17]. Humor is appreciated differently from one culture to another, from one region to another, from one person to another. This form of expression presents a risk that relates to the difficulty of understanding the message. The use of humor is tricky Teyssier [26]. It can sometimes disturb the receiver. Caples in Brochand [43] states that humor must be used with caution because public reactions are unpredictable and remain very personal. He recommends 'to avoid humor: what is fun for a person is not for millions. the role of advertising is to sell not to entertain'. Therefore, some doubt about the ethical use of humor Teyssier [26]. Simpson [49] argues that advertisements may contain elements that some of the target finds unethical such as nudity, humor and fear appeals. He underlines that the ethical judgment of advertising has a positive effect on responses to an advertising message. Simpson [49] reports that the perception of the non-ethicity of advertising negatively affects the attitude 
towards advertising, the attitude toward the brand and the intention to purchase. Vittel 1991 and Whalen 1991 argue that ethical judgment has an influence on consumer behavior.

Benatar [50] argues that humour is worthy of serious ethical consideration. Ethical questions are typically thought to arise in certain predictable categories of humor. It consists for example of racial, ethnic and gender humour. This category includes jokes about 'blacks', and women. Another is humor about religious figures and other sacred matters. We might refer to this as blasphemous humour. The third category is called scatological humour, it includes jokes about genitalia, sex, urination, defecation and other bodily effluvia. Tragic or morbid humour is a category of humor about death and suffering. It includes dead baby jokes, and making light of famine and disease. Humor about people's personal attributes, such as their big ears or noses their short or tall statue, or their mental or physical disabilities Benatar [50].

Many researchers focus on the interaction between humor and ethics Berys [51]; Caroll [52]; Roberts 2016. The paper of Roberts 2016 considers of how immoral elements in instances of humor affect funniness. He adds that Comic ethicism is the position that each immoral element negatively affects funniness and if their cumulative effect is sufficient, then funniness is eliminated. Caroll [52] has criticized the merited response argument as illegitimately conflating comic merit with moral merit. We can propose the following assumptions:

H2: The ethical judgment of humorous advertising has an effect on persuasion.

H3: The ethical judgment of a humorous advertisement has an effect on the intention to quit smoking.

\section{Methodology}

\section{Choice of method of data collection: experimental design}

Participants are exposed to two TV spots. The first one is humorous, the second is slightly humorous. The procedure for selecting the advertising medium is done in two stages: First, we downloaded from the Internet fifteen anti-smoking spots. Two experts in marketing and preventive medicine choose, in a second step, the humorous spot. This same spot is subject to modifications to cause a low level of humor. The choice of the message was made on the basis of certain criteria. We had to find an advertisement which easily manipulated because our goal is to transform an initially humorous advertisement into an informative advertisement. We also pre-tested these two spots with 35 students from the Institute of Applied Studies in Humanities of Kef and the Faculty of Economics and Management of Jendouba to check their ability to trigger humor in the desired level: 20 participants watched the humorous spot, 15 individuals were exposed to the informative spot.To check how humorous, the advertisement was perceived by the participant, the humor scale of Zhang [11] was used. This scale consists of 5 bi-polar items not humorous/humorous, not funny/funny; not playful/ playful; not amusing/amusing and not dull/dull.

After broadcasting the humorous ad, participants respond to questions relating to perceived humor and morality of the ads and fill a questionnaire which assesses their intention to stop smoking and their degree of persuasion. This procedure was repeated for the second spot. The sample consists of smokers.

\section{Measures}

All indicators are measured by a 5-point Likert scale ranging from 'Strongly Disagree' to "Strongly Agree". The various measurement scales used and the sources are presented in Table 1.

Table 1: Presentation of measurement scales.

\begin{tabular}{|c|c|}
\hline Concepts & Source \\
\hline Persuasion & Keller (1999) \\
\hline Behavioral intention & Pierce et al.in Pechmann et al. (2003) \\
\hline Ethical judgement & Reideinbach and Robin (1990) \\
\hline Perception of humour & Zhang (1996) \\
\hline
\end{tabular}

\section{Results}

\section{Sample description}

The questionnaires are administered directly to 390 respondents to assist them and reduce the risk of non-response by choosing to interview them in classrooms and in their offices. After the spot is broadcast, individuals are asked to complete a questionnaire that assesses their ethical judgment, degree of persuasion and intention to stop smoking. Most of the interviews are students aged 20 to 29 years (94\%). Men are a priority among the participants (79\%).

\section{Post-test check on the success of the humor manipulation}

In order to facilitate a post test check on the success of the humor manipulation, the items of the scale of perceived humor were preceded by instructions to: Please indicate the extent to which you agree with the following statements by circling the appropriate numbers "The advertisement that I was just saw was............... Responses were summed and averaged. Alpha reliability of the scale was 0.97 .

\section{Manipulation Check}

An analysis of variance (ANOVA) examined the effect of the humor treatment on perceived humor. Results show a significant main effect of the humor treatment on the perceived humorousness of the ad. Mean scores of the humor scale were 2.3 for the lower humor treatment group, 4.6 for the higher humor treatment group. Study of the scales 


\section{Exploratory Analysis}

\section{Analysis of the dimensionality and reliability of the ethical judgments scale}

Principal component analysis revealed a satisfactory KMO of 0.666 and a significant Bartlett sphericity test. Principal component analysis reveals the existence of two dimensions (Table 2).

Table 2: Dimensionality and reliability of the 'ethical judgment' scale.

\begin{tabular}{|c|c|c|}
\hline This advertising is fair. & Moral equity & Relativism \\
\hline This advertisement is just. & 0.745 & \\
\hline $\begin{array}{c}\text { This advertisement is morally } \\
\text { correct. }\end{array}$ & 0.774 & \\
\hline $\begin{array}{c}\text { This advertisement is acceptable to } \\
\text { my family. }\end{array}$ & 0.896 & 0.892 \\
\hline $\begin{array}{c}\text { This advertisement is acceptable in } \\
\text { my culture. }\end{array}$ & & 0.888 \\
\hline $\begin{array}{c}\text { This advertisement is traditionally } \\
\text { acceptable. }\end{array}$ & 46.551 & 26.532 \\
\hline Percentage of variance & 0.848 & 0.742 \\
\hline Cronbach Alpha & \\
\hline
\end{tabular}

Analysis of the dimensionality and reliability of the scale of the intention to stop smoking

Principal component analysis indicated a KMO of 0.605 and a significant Bartlett sphericity test.We eliminate the item 'if one of your best friends offers you a cigarette, you will smoke it' because it has a poor quality of representation (Table 3).

Table 3: Dimensionality and reliability of the scale of intention to quit smoking.

\begin{tabular}{|c|c|}
\hline $\begin{array}{c}\text { Henceforth, you will smoke a puff or } \\
\text { more than one cigarette. }\end{array}$ & Intention to quit smoking \\
\hline $\begin{array}{c}\text { Now you are going to quit smoking } \\
\text { for a period of time. }\end{array}$ & 0.868 \\
\hline Cronbach Alpha & 0.868 \\
\hline
\end{tabular}

Analysis of the dimensionality and reliability of the scale of persuasion

Table 4: Dimensionality and reliability of the persuasion scale.

\begin{tabular}{|c|c|}
\hline $\begin{array}{c}\text { I am persuaded by the information conveyed by this } \\
\text { advertisement. }\end{array}$ & Persuasion \\
\hline This advertising is convincing. & 0.922 \\
\hline $\begin{array}{c}\text { I will adopt the recommendation conveyed by this } \\
\text { message in the future. }\end{array}$ & 0.935 \\
\hline $\begin{array}{c}\text { After watching this advertisement, I would no longer } \\
\text { be tempted to smoke. }\end{array}$ & 0.803 \\
\hline Cronbach Alpha & 0.893 \\
\hline
\end{tabular}

Principal component analysis indicated an excellent KMO of 0.819 and a significant Bartlett Sphericity test. We eliminated the items "this message will influence my future decisions" and 'I will be more receptive about information of tobacco abuse" because they have a poor quality of representation (Table 4).

\section{Analysis of the dimensionality and reliability of the scale of perception of humor}

The KMO index is equal to 0.693 . It is considered satisfactory since it is close to 1 . Principal component analysis reveals the existence of a single factor with an Eigen value greater than 1, that is, 2.962. We eliminated an item «this advertisement is dull» because it has a representation quality of less than 0.5 . The Table 5 below illustrates the results of the exploratory factor analysis applied to the perception of humor scale.

Table 5: Dimensionality and Reliability of the Scale of Perception of Humor.

\begin{tabular}{|c|c|}
\hline & Dimension \\
\hline This advertisement is humorous & 0.926 \\
\hline This advertisement is funny & 0.798 \\
\hline This advertisement is playful & 0.805 \\
\hline This advertisement is amusing & 0.906 \\
\hline Cronbach's Alpha Score & 0.879 \\
\hline
\end{tabular}

\section{Confirmatory Analysis}

\section{Reliability and convergent validity of persuasion scale}

The Jöreskog'srhôindicates a value greater than 0.7 for the construct "persuasion". In addition, the procedure of Fornell [53] was followed to calculate the convergent validity. The Rho of convergent validity indicates a value that exceeds the minimum threshold of 0.5 (Table 6).

Table 6: Reliability and convergent validity of persuasion scale.

\begin{tabular}{|c|c|}
\hline $\begin{array}{c}\text { I am persuaded by the information conveyed by } \\
\text { this advertisement }\end{array}$ & 0.92 \\
\hline This advertising is convincing & 0.98 \\
\hline Jöreskog'srhô & 0.95 \\
\hline Rho of convergent validity & 0.9 \\
\hline
\end{tabular}

Reliability and convergent validity of the scale of intention to quit smoking

The Jöreskog'srhôindicates a value greater than 0.7 for the construct "intention to quit smoking". In addition, the procedure of Fornell [53] was followed to calculate the convergent validity. The Rho of convergent validity indicates a value that exceeds the minimum threshold of 0.5 (Table 7).

Table 7: Standardized factor loadings of the scale 'INTENTION TO QUIT SMOKING'.

\begin{tabular}{|c|c|}
\hline & $\boldsymbol{\lambda}_{\mathbf{i}}$ \\
\hline Henceforth, you will smoke a puff or more than one Cigarette. & 0.79 \\
\hline Now you are going to quit smoking for a period of time. & 0.75 \\
\hline Jöreskog'srhô & 0.74 \\
\hline Rho of convergent validity & 0.59 \\
\hline
\end{tabular}


Reliability, convergent and discriminating validity of the of the construct "ethical judgment"

It can be seen from the following table that the Jöreskog'srhô indicates values greater than 0.7 for each of the dimensions obtained. Moreover, the procedure of Fornell [53] was used to calculate convergent validity and discriminant validity. The Rho of convergent validity indicates satisfactory values which exceed the minimum threshold of 0.5 . In addition, the conditions of discriminating validity are respected as shown in Table 8. Therefore, we can say that the dimensions obtained from ethical judgment are reliable and valid.

Table 8: Reliability, convergent validity, and discriminating of the construct 'Ethical Judgment”.

\begin{tabular}{|c|c|c|}
\hline & Moral equity (F1) & Relativism (F2) \\
\hline Jöreskog'srhô & 0.85 & 074 \\
\hline Rho of convergent validity & 0.61 & 0.88 \\
\hline Discriminant validity & $\left(\mathrm{R}^{2} 12\right)=0.001$ & $0.001<0.88$ \\
\hline
\end{tabular}

Reliability and convergent validity of the perception of humor scale

The Rhô de Jöreskog indicates a value greater than 0.7 for the constructed «perception of humor». In addition, the procedure of Fornell [53] was followed to calculate the convergent validity. The Rhô of convergent validity indicates a value that exceeds the minimum threshold of 0.5 (Table 9). The confirmatory analysis makes it possible to test the reliability and the validity of the constructs. The Rhô de Jöreskog indicates values greater than 0.7 for the four constructs. In addition, the procedure of Fornell [53] was followed to calculate the convergent validity. The Rhô of convergent validity indicates values that exceed the minimum threshold of 0.5 . Therefore, we can say that the four constructs are reliable and valid.

Table 9: Reliability and convergent validity of the perception of humor scale.

\begin{tabular}{|c|c|}
\hline & $\boldsymbol{\lambda}_{\mathbf{i}}$ \\
\hline This advertisement is humorous. & 0.981 \\
\hline This advertisement is amusing. & 0.986 \\
\hline Jöreskog'sRhô & 0.98 \\
\hline Rhô of convergent validity & 0.96 \\
\hline
\end{tabular}

Hypotheses Testing

\section{Hypotheses 1: Persuasion has an effect on intention to quit smoking}

Table 10: Test result of hypothesis 1.

\begin{tabular}{|c|c|c|c|}
\hline Causal link & $\begin{array}{c}\text { Student's } \\
\text { test }\end{array}$ & $\mathbf{p}$ & $\begin{array}{c}\text { Standardized } \\
\text { Coefficient }\end{array}$ \\
\hline $\begin{array}{c}\text { Persuasion } \rightarrow \text { intention to stop } \\
\text { smoking }\end{array}$ & 3.266 & 0.001 & 0.288 \\
\hline
\end{tabular}

The results indicate that persuasion has a positive effect on the intention to quit smoking as illustrated in Table 10. The hypothesis $\mathrm{H} 1$ is supported. The fitting quality of the model is acceptable. The NFI is equal to 0.99 . The CFI is equal to 1 . The RMSEA is equal to 0.000 .

\section{Hypotheses 2: Ethical judgments of advertising has an impact on persuasion}

The results indicate that ethical judgments of advertising have an impact on persuasion (Table 11). The hypotheses $\mathrm{H} 2$ are partially verified.

Table 11: Test result of hypothesis 2 .

\begin{tabular}{|c|c|c|c|}
\hline Causal link & $\begin{array}{c}\text { Student's } \\
\text { test }\end{array}$ & $\mathbf{p}$ & $\begin{array}{c}\text { Standardized } \\
\text { Coefficient }\end{array}$ \\
\hline Moral equity $\rightarrow$ persuasion & 6.869 & 0.000 & 0.657 \\
\hline Relativism $\rightarrow$ persuasion & 0.417 & 0.676 & 0.028 \\
\hline
\end{tabular}

\section{Hypotheses 3: The ethical judgments of advertising} have an effect on the intention to quit smoking.

Hypotheses 3is partially verified (Table 12). The fitting quality of the model is good. The RMR is approaching zero. It is equal to 0.02 . The NFI is equal to 0939 . The CFI is equal to 0.969 . The RMSEA is equal to 0.07 .

Table 12: Test result of hypothesis 3.

\begin{tabular}{|c|c|c|c|}
\hline Causal link & $\begin{array}{c}\text { Student's } \\
\text { test }\end{array}$ & $\mathbf{p}$ & $\begin{array}{c}\text { Standardized } \\
\text { Coefficient }\end{array}$ \\
\hline $\begin{array}{c}\text { Relativism } \rightarrow \text { intention to quit } \\
\text { smoking }\end{array}$ & 2.24 & 0.02 & 0.22 \\
\hline $\begin{array}{c}\text { Moral equity } \rightarrow \text { intention to } \\
\text { quit smoking }\end{array}$ & 1.116 & 0.26 & 0.1 \\
\hline
\end{tabular}

\section{Results}

The hypothesis concerning the link between ethical judgment and persuasion is confirmed. Ethical judgment therefore has an important effect on persuasion. These results are similar to those of Simpson [49]; Mostafa [22]. As such, unethical advertisements can have very negative repercussions in the short and long term Hyman [19]; Thompson [23]; Palmer-Mehta [25]; Eckart [24]. The use of shocking advertisements that offend the sensitivity of smokers can cause boredom and rejection among prospects that become more and more indifferent to them. The perception of the advertiser's manipulative intention weakens his ability to persuade them: if the viewer perceives that the message is ethical, he will accept the advertising argument and adopt the advertiser's recommendation. These results are similar with those who previously obtained in the literature and highlight the role of perception of the ethical character of humorous advertising on persuasion. There is a growing social demand for advertising to assume itself as a responsible activity. De George [54] denoted that 'Morality is the oil as well as the glue of society and business'. Advertisers should spend great efforts in achieving consumer acceptance and trust. Ethical communication is a very crucial element to consumers' decision process. Consequently, organizations ought to rely on ethical communication to reach the target successfully. This study is further distinguished by the integration of ethics to explain persuasion and the intention 
to quit smoking. The proposed model focuses on the ethical dimension in order to describe the process of information from a humorous message. The theoretical framework within which our research is based on Habermas [38,39] theory of communicative action. He points out that the effectiveness of advertising is best achieved by using intercomprehension communications. It's important to abandon instrumental and strategic communications. Getting people to adopt healthy behaviors that conform standards requires the use of means that already meet these standards.

Communication practices should be a model of compliance with these standards. They should bear in themselves the respect for the dignity of the individual. This study also provides managerial input, as it explains the relationships between potentially acting concepts on persuasion and intention to quit smoking, thereby enlightening public advertisers on the issue of effectiveness and the moral legitimacy of humor in social communications and provide them with a work base and a theoretical framework to assist them design persuasive and ethical anti-smoking messages. Analysis of the literature and experimentation could be useful for communication professionals who want to use humor in their campaign. Finally, our research reveals the importance of using humor to fight tobacco. The review of the literature reveals that fear is widely used in public health campaigns. However, there is a lack of research on the theme of humor and social persuasion. Surprise can be a privileged means available to creative advertising agencies to capture the attention of consumers and smokers Makhlouf [55].

However, there are some limitations to this research: smokers are under forced exposure conditions that are far from the real context of reception of advertisements. In addition, they watched it once. However, in reality, they can look at it many times. This could influence persuasion. For example, repeated exposure to these communications can cause boredom and reduce persuasion. It would be wise to perform a longitudinal research of the impacts of humorous advertising as part of a repetition of exhibitions. In addition, we did not measure actual behavior in order to verify the real impact of ethical judgments on behaviors [56-66].

\section{References}

1. World Health Organization (1999) World health report making a Difference. Geneva, Switzerland.

2. Fakhfakh R, Hsairi M, Achour N (2005) Epidemiology and prevention of tobacco use in Tunisia: a review. Prev Med 40(6): 652-657.

3. Fakhfakh R, Achour N, Klouz A, Salah FB, Lakhal M, et al. (2011a) Determinants of tobacco use habits among hospital staff in Tunisia. Prev Med 52(6): 478-479.

4. Smith K, Stutts MA (2003) Effects of short-term cosmetic versus long-term health fear appeals in anti-smoking advertisements on the smoking behaviour of adolescents. Journal of Consumer Behaviour 3(2): 157-177.
5. Lewis, Ioni M, Watson, Barry C, Tay, et al. (2007) The role of fear appeals in improving driver safety: a review of the effectiveness of fear arousing (threat) appeals in road safety advertising. International Journal of Behavioral and Consultation Therapy 3(2): 203-222.

6. Paquette G, Pénélope D (2005) L'évaluation des campagnes de sécurité routière; problématique et méthodologie, Québec, Université Laval, Département d'information et de communication, Groupe de recherche en sécurité routière.

7. Fleur L, Miletto V (2003) Santé et prevention : les jeunes en parlent, parlons-en..." Colloque Régional, Marseille.

8. Oddoux K (2001) Les Jeunes et la Communication sur la Santé. Service Etudes et Evaluations du CFES, La Santé de l'Homme n 352.

9. Riou N (2005) Peur sur la Pub. Eyrolles. Roberts A Humour is a funny thing. The British Journal of Aesthetics 56(4): 355-366.

10. Madden T, Weinberger MG (1982) The effects of humor on attention in magazine advertising. Journal of Advertising 11(3): 8-14.

11. Zhang Y (1996) Responses to humorous advertising: the moderating effect of need for cognition. Journal of advertising 25(1): 15-33.

12. Zhang Y, Zinkhan GM (2006) Responses to humorous ads. Journal of Advertising 35(4): 113-128.

13. Brooker G (1981) A Comparison of the persuasive effects of mild humor and mild fear appeals. Journal of Advertising 10(4): 29-40.

14. De Barnier V, Maille V, Valette-Florence P, Gallopel K (2004) Impact des messages à Caractère choquant sur la persuasion publicitaire: Une étude interculturelle. Actes du XXe Congrès AFM 6-7 Mai, St Malo.

15. Kapferer JN (1990) Les chemins de la persuasion. Le mode d'Influence des Media et de La Publicité sur les Comportements Dunod.

16. Gallopel K, Petr C (2000) Utilisation de la Peur dans les Campagnes de Prévention des Comportements Tabagiques: Résultats et Discussions autour des Jeunes Français. Actes du Colloque Universita Ca' Foscari 28.

17. Graby F (2001) Humour et Comique en Publicité. Éditions EMS.

18. Hastings G, Stead M, Webb J (2004) Fear Appeals in Social Marketing: Strategic and Ethical Reasons for Concern. Psychology \& Marketing 21(11): 961-987.

19. Hyman MR, Tansey R (1990) The Ethics of Psychoactive Ads. Journal of Business Ethics 9(2): 105-114.

20. Gallopel K (2006) Peur \& Persuasion sociale : Etat de Lart Limites et Voies de Recherche. Actes du XXII ${ }^{\circ}$ Congrès AFM-11 \& 12 Mai NANTES.

21. Derbaix C, Grégory P (2004) Persuasion: La theorie de l'irrationalite restreinte. Economica 1: 256.

22. Mostafa MM (2011) An investigation of egyptian consumers' attitudes toward ethical issues in advertising. Journal of Promotion Management 17(1): 42-49.

23. Thompson LE, Barnett JR, Pearce JR (2009) Scared straight? fearappeal anti-smoking campaigns, risk, self-efficacy and addiction. Health Risk \& Society 11(2): 181-196.

24. Eckart J (2011) Mind Control Tactic-Fear Appeal. NLP \& Hypnosis 5: 1.

25. Palmer Mehta V (2009) Motivational Appeals and Ethics. Communication Teacher 23(1): 41-47.

26. Teyssier JP (2004) Frapper sans Heurter: Quelle Ethique pour la Publicité? Armand Colin.

27. Alden DL, Hoyer WD (1993) An Examination of Cognitive Factors Related to Humorousness in Television Advert J Adver 22(2): 29-38. 
28. Snipes RL, La Tour MS, Bliss SJ (1999) A model of the effects of selfefficacy on the perceived ethicality and performance of fear appeals in advertising. Journal of Business Ethics 19(3): 273-285.

29. Reindenbach RE, Robin DP (1990) Toward the development of multidimensional scale of improving evaluations of business ethics. Journal of Business Ethics 9(8): 639-653.

30. La Tour MS, Henthorne TL (1994) Ethical judgement of sexual appeals in print advertising, Journal of Advertising 23(3): 81-90.

31. Fishbein M, Ajzen A (1975) Beliefs, attitudes, intention and behavior: an introduction to theory and research. Reading MA Addison-Wesley.

32. Ajzen I (1991) The theory of planned behavior. Organizational Behavior and Human Decision Processes, 50(2): 179-211.

33. Eagly AH, Chaiken Shelly (1993) The Psychology of attitudes. For Worth Harcourt Brace Javanivich College 794.

34. Ajzen I (1985) From intentions to actions: A theory of planned behavior. In Kuhl J \& Beckmann J (Eds.), Action-control: From cognition to behavior pp. 11-39.

35. Fishbein M (1980) A theory of reasoned action: some applications and implications. Nebr Symp Motiv 27: 65-116.

36. Preston P (2005) Persuasion: what to Say, how to Be. Alabama Journal of Health Care Management 50(5): 294-296.

37. Dacheux E (1994) Les Stratégies de Communication Persuasive dans l'Union Européenne. Harmattan 283.

38. Habermas J (1987a) Théorie de l'agir communicationnel. Fayard.

39. Habermas J (1987b) Théorie de l'agir communicationnel. Fayard.

40. Festinger L, Maccoby N (1964) On resistance to persuasive communications. Journal of Abnormal and Social Psychology 68(4): 359-366.

41. Wells, Petty (1980) The effects of overt head movements on persuasion: compatibility and incompatibility of response. Basic and Applied Social Psychology 1(3): 219-230.

42. Petty RE, Wells GL, Brock TC (1976) Distraction can enhance or reduce yielding to propaganda: Thought disruption versus effort justification. Journal of Personality and Social Psychology 34: 874-884.

43. Brochand, Lendrevie (1993) Love the ad, buy the product. Le Publicitor Paris 21-25.

44. Weinberger GM, Gulas CS (1992) the impact of humor in advertising: a review. journal of advertising 21(4): 35-59.

45. Elgozy G (1979) De l'Humour; Tout un Art de Vivre. Edition Denoël.

46. Madden T, Weinberger MG (1982) The effects of humor on attention in magazine advertising. Journal of Advertising 11(3): 8-14.

47. Biel AL, Bridgewater CA (1990) Attributes of Likable Television Commercials. Journal of Advertising Research 30: 38-44.

48. Mc Quirrie EF, Mick DG (2003) Visual and verbal rhetorical figures under directed processing versus incidental exposure to advertising. Journal of Consumer Research 29(4): 579-587.
49. Simpson PM, Brown G, Widing RE (1998) The association of ethical judgment of advertising and selected advertising effectiveness response variables. Journal of Business Ethics 17(2): 125-137.

50. Benatar D (2017) Taking humour (Ethics) seriously, But not too Seriously. Journal of Practical Ethics.

51. Berys G (1998) Just joking: The Ethics and Aesthetics of Hmor. Philosophy and Literature 22(1): 51- 68.

52. Carroll N (2014) Ethics and Comic Amusement. The British Journal of Aesthetics 54(2): 241-253.

53. Fornell C, Larcker DF (1981) Evaluating structural equation models with unobservable variables and measurement error. Journal of Marketing Research 18(1): 39-50.

54. De George R (2009) Business Ethics-7 $7^{\text {th }}$ edn. Pearson.

55. Makhlouf Khaddouma Mouna (2011) Intégration de l'effet surprise dans les modèles de persuasion publicitaire. Thèse de doctorat en Sciences de gestion.

56. Gallopel MK, Gabriel P, Le Gall EM, Rieunier S, Urien B (2011) the use of visual warnings in social marketing: the case of tobacco. Journal of Business Research 64(1): 7-11.

57. Ajzen I (2002) Perceived behavioural control, self-efficacy, locus of control, and the theory of planned behavior1. J App Soc Psy 32(4): 665-683.

58. Bass K, Barnett T, Brown G (1999) Individual difference variable, Ethical Judgment and ethical behavioral intention. Business Ethics Quarterly 9(2): 183-205.

59. Dillard JP (1994) Rethinking the Study of Fear Appeals: An Emotional Perspective. Communication Theory 4: 295-323.

60. Duncan PC, Neslson EJ, (1985) Effects of Humor in a Radio Advertising Experiment. Journal of Advertising, 14(2): 33-64.

\section{Enquêtes DMSU (2000) Tunisie.}

62. Fakhfakh R, Hsairi M, Belaaj R, Ben Romdhane H, Achour N (2001) Epidemiology and prevention of smoking in Tunisia: current situation and perspective. Arch Inst Pasteur Tunis 78(1-4): 59-67.

63. Salah Al NM, Sahar AAH, Jawad Ahmed Al, Yousuf Sulaiman Al, Sulaiman Nasser Al R (2010) Global youth tobacco survey, Tunisia.

64. Keller AP (1999) Converting the Unconverted: The Effect of Inclination and Opportunity to Discount Health-Related Fear Appeals. J Appl Psychol 84(3): 403-415.

65. Pechmann C, Zhao G, Marvin EG, Reibling ET (2003) What to Convey in Antismoking Advertisements for Adolescents: The use of Protection Motivation Theory to identify Effective Message Themes. Journal of Marketing 67(2): 1-18.

66. Thiétart RA (1999) Méthodes de recherche en management. Dunod. 
CC (i) This work is licensed under Creative BY DOI: $10.19080 /$ PBSIJ.2018.09.555752
Your next submission with Juniper Publishers will reach you the below assets

- Quality Editorial service

- Swift Peer Review

- Reprints availability

- E-prints Service

- Manuscript Podcast for convenient understanding

- Global attainment for your research

- Manuscript accessibility in different formats ( Pdf, E-pub, Full Text, Audio)

- Unceasing customer service

Track the below URL for one-step submission https://juniperpublishers.com/online-submission.php 